\title{
Effect of 17 $\beta$-estradiol in rat bone marrow-derived endothelial progenitor cells
}

\author{
JIN-CHENG ZHANG and GANG LÜ
}

\begin{abstract}
Department of Orthopedics, The First Affiliated Hospital of China Medical University, Shenyang, Liaoning 110001, P.R. China
\end{abstract}
Received January 16, 2013; Accepted May 13, 2013

DOI: $10.3892 / \mathrm{mmr} .2013 .1486$

\begin{abstract}
The aim of the present study was to investigate the bionomics of rat bone marrow endothelial progenitor cells (EPCs) following 17 $\beta$-estradiol treatment at various concentrations. Total mononuclear cells were extracted from rat bone marrow by density gradient centrifugation. Following cultivation for 7 days, attached cells were incubated with various concentrations of $17 \beta$-estradiol $(0,10$ and $100 \mathrm{nmol} / \mathrm{l})$. The proliferation and migration activities of EPCs were measured by MTT and transwell chamber assays. In vitro vasculogenic activities were measured using type I collagen. Flow cytometry was performed to analyze differentiation into endothelial cells. The results indicated that at 7 days following culture, CD133 and CD34 cell markers were 69.44 and $81.05 \%$, respectively. MTT assay demonstrated that the optical density (OD) value of the $10 \mathrm{nmol} / 1$ group was markedly higher than that of the 0 and $100 \mathrm{nmol} / 1$ groups. The OD value of the $0 \mathrm{nmol} / \mathrm{l}$ group was higher than the $100 \mathrm{nmol} / \mathrm{l}$ group $(\mathrm{P}<0.05)$. EPC migration, in vitro vascularization and differentiation were higher in the 100 and $10 \mathrm{nmol} / \mathrm{l}$ groups compared with the $0 \mathrm{nmol} / \mathrm{l}$ group. These parameters were higher in the $100 \mathrm{nmol} / \mathrm{l}$ than the $10 \mathrm{nmol} / 1$ group $(\mathrm{P}<0.05)$. In conclusion, the results of the present study demonstrated that migration, in vitro vasculogenesis and differentiation into endothelial cells is regulated by $17 \beta$-estradiol and enhanced in a concentration-dependent manner. Proliferation levels were contrary to these observations, with levels decreasing as the concentration of $17 \beta$-estradiol increased.
\end{abstract}

\section{Introduction}

Endothelial progenitor cells (EPCs), the precursor cells of vascular endothelial cells, migrate to the peripheral circulation and differentiate into mature endothelial cells. These cells are important for repair of damaged vascular endothelium, partici-

Correspondence to: Professor Gang Lü, Department of Orthopedics, The First Affiliated Hospital of China Medical University, 92 Beier Street, Shenyang, Liaoning 110001, P.R. China E-mail: lvgang_bone@163.com

Key words: endothelial progenitor cells, 17 $\beta$-estradiol, biological function pating in neoangiogenesis and maintaining the integrity of the vascular endothelium (1). Certain previous studies showed that estrogen use may reduce the risk of heart failure in female cardiovascular disease patients, suggesting a protective role of estrogen in the cardiovascular system. The mechanism may involve EPCs. $17 \beta$-estradiol is an estrogen, which promotes the homing and proliferation of vascular endothelial cells (2). $17 \beta$-estradiol and EPCs have been found to participate in the repair of damaged vessels and angiogenesis (3). The long-term use of high-dose estrogen may lead to breast cancer, blood clot diseases as well as other adverse results. Yet the effects of low-dose estrogen therapy on circulating EPCs are unknown. The present study investigates the effect of $17 \beta$-estradiol at various concentrations on the biological characteristics of rat bone marrow-derived EPCs, to provide an experimental basis and clinical reference for the application of $17 \beta$-estradiol and EPCs in vascular tissue and bone tissue engineering.

\section{Materials and methods}

Experimental animals, reagents and instruments. Twenty Wistar rats (4 weeks old) were provided by the Laboratory Animal Center of China Medical University (Shengyang, Liaoning, China). All experimental procedures were performed in accordance with the Guidelines for the Care and Use of Laboratory Animals, formulated by the Ministry of Science and Technology of the People's Republic of China. The study was approved by the ethics committee of The First Affiliated Hospital of China Medical University, Shenyang, China. M199 medium and fetal bovine serum were obtained from Gibco-BRL (Carlsbad, CA, USA). Lymphocyte separation medium was purchased from Tianjin Haoyang Biologicals Technology Co., Ltd (Tianjin, China), 17 $\beta$-estradiol was obtained from Sigma-Aldrich (St. Louis, MO, USA), CD133, CD34 and CD31-labeled antibodies from Wuhan Boster Biological Technology Co., Ltd (Wuhan, Hubei, China) and Transwell chambers from Corning, Inc. (NY, USA).

Isolation, culture and identification of cells. The tibia and femur were separated under sterile conditions and the marrow cavity was flushed with M199 medium. The irrigation fluid was collected and mixed fully prior to centrifugation with lymphocyte separation medium (density gradient, $1.077 \mathrm{~g} / \mathrm{cm}^{3}$; volume ratio, irrigation liquid to separated liquid was $2: 1$ ). Ficoll-Histopaque gradient centrifugation was conducted at 
$20^{\circ} \mathrm{C}$ at $384 \mathrm{x} \mathrm{g}$ for $20 \mathrm{~min}$. The mononuclear cell layer in the middle was removed and washed in PBS prior to inoculation into a $100 \mathrm{ml}$ culture flask at a density of $1 \times 10^{6}$ cells $/ \mathrm{ml}$. Cells were cultured in M199 medium containing 20\% fetal bovine serum in a $5 \% \mathrm{CO}_{2}$ saturated humidity incubator at $37^{\circ} \mathrm{C}$ for $48 \mathrm{~h}$ prior to re-vaccination of non-adherent cells. Half of the medium was changed on the third day with whole replacement on the fifth day. Cells were digested with $0.25 \%$ trypsin (containing 1\% EDTA) when cell fusion reached $>80 \%$. On the seventh day, CD133 and CD34 phenotypes were identified with a flow cytometer.

Proliferation assay. Adherent cells were collected and counted. EPC suspension $(200 \mu \mathrm{l})$ was inoculated in a 96 -well plate for $48 \mathrm{~h}$ with various concentrations of $17 \beta$-estradiol $(0,10,100 \mathrm{nmol} / \mathrm{l})$ following $24 \mathrm{~h}$ culture in M199 culture medium without fetal bovine serum. Each concentration was repeated in 5 wells. After $24 \mathrm{~h}, 20 \mu \mathrm{l}$ MTT (5 g/l) was added and incubated for $4 \mathrm{~h}$, followed by replacement with DMSO $(150 \mu \mathrm{l} /$ well $)$ and agitation for $10 \mathrm{~min}$. The plate was read at $560 \mathrm{~nm}$ on the microplate reader. The average optical density (OD) values of five wells were used to obtain the optimal concentration for cells. Incubation time was used as the abscissa and the OD value as the ordinate for cell growth curve.

Migration assay. In vitro migration assay was performed in a 24-well Transwell chamber (pore size, $8 \mu \mathrm{m}$ ). EPC suspension $\left(200 \mu \mathrm{l} ; 1 \times 10^{4}\right.$ cells $\left./ \mathrm{ml}\right)$ was added into the upper chamber with M199 medium containing various concentrations of $17 \beta$-estradiol $(0,10$ and $100 \mathrm{nmol} / \mathrm{l})$ in the lower chamber. Cells were cultured for $24 \mathrm{~h}$ and cells attached to the upper chamber were removed with a wet cotton swab. The cells were fixed and stained using the Giemsa method. The experiment was repeated three times.

In vitro angiogenesis assay. Fibrin gel was used for in vitro angiogenesis experiments. Artificial fibrinogen $(30 \mu \mathrm{l})$ and $20 \mu \mathrm{l}$ thrombin were added in sequence to 96 -well plates and agitated prior to incubation at $37^{\circ} \mathrm{C}$ for gel formation. Cells $\left(5 \times 10^{3}\right)$ were added and cultured overnight. Next, the culture medium was removed and $30 \mu \mathrm{l}$ artificial fibrinogen and $20 \mu \mathrm{l}$ thrombin was added in sequence. Culture medium containing various concentrations of $17 \beta$-estradiol $(0,10$ and $100 \mathrm{nmol} / \mathrm{l})$ was added and incubated for an additional $24 \mathrm{~h}$. Angiogenesis was observed and three visual fields (magnification, x200) were selected for blood vessel counting.

Effect of $17 \beta$-estradiol on EPC-induced differentiation. Differentiation was assessed on day 4 of primary cell culture. The culture medium was changed to M199 medium containing various concentrations of $17 \beta$-estradiol (10 and $100 \mathrm{nmol} / \mathrm{l}$ ) for $24 \mathrm{~h}$ and flow cytometry was performed. Adherent cells were digested with trypsin for single cell suspension solution and centrifuged at $384 \mathrm{x}$ g for $5 \mathrm{~min}$. Cells were resuspended in $50 \mu \mathrm{l}$ PBS, a CD31-labeling antibody was added and incubated at $4^{\circ} \mathrm{C}$ for $60 \mathrm{~min}$. Flow cytometry was performed in the dark immediately following PBS washing and re-suspension. PBS was used as the isotype control. WinMDI2.9 software was used to calculate the percentage of $\mathrm{CD} 31^{+}$cells.
Statistical analysis. Data are presented as the mean \pm SD and SPSS 10.0 software was used (SPSS, Inc., Chicago, IL, USA) for statistical analysis. Univariate, multifactorial analysis of variance was performed and t-tests were performed to compare between groups. The LSD method was used for the multiple group comparison. $\mathrm{P}<0.05$ was considered to indicate a statistically significant difference.

\section{Results}

Identification of cell morphology and phenotype. Freshly isolated mononuclear cells were small, round and evenly distributed in the suspension. Cells adhered to the wells $24 \mathrm{~h}$ post-inoculation and gradually grow into a slender spindle or irregular polygon morphology. One week following the removal of unattached cells from the suspension, a small colony was observed and at two weeks, a large colony had formed. At three weeks, colonies had connected and the shape of adherent cells had changed from slender to short, representative of a typical paving stone-like appearance. Vacuoles were observed in the cytoplasm, indicative of aging.

Cells that adhered to the wells after being replated were purified on day 7 of culture. The CD133-positive rate of primary cells was $69.44 \%$ and the CD34-positive rate was $81.05 \%$ (Fig. 1). These results indicate that the extracted, separated and purified cells are endothelial progenitor cells.

Effect of VEGF on EPC proliferation. Average OD values of the 0,10 and $100 \mathrm{nmol} / 1$ groups were $0.3490 \pm 0.0332,0.6278 \pm 0.0796$ and $0.2758 \pm 0.0125$, respectively and OD was found to be significantly different in the 10 and $100 \mathrm{nmol} / \mathrm{l}$ groups compared with the $0 \mathrm{nmol} / 1$ group $(\mathrm{P}<0.05) .17 \beta$-estradiol was found to have a significant effect on EPC proliferation, improving the proliferation of EPCs; however, as the concentration of $17 \beta$-estradiol increased, EPC proliferation weakened. The 0 and $10 \mathrm{nmol} / \mathrm{l}$ groups were selected to generate a cell growth curve (Fig. 2) revealing the following observations: the first three days post-inoculation is the incubation period, in which cells begin to grow adherent to the well with low levels of cell proliferation; following three days, cell proliferation accelerates and proliferation in the $10 \mathrm{nmol} / 1$ group was markedly higher than that of $0 \mathrm{nmol} / \mathrm{l}$. This trend continued to the end of primary culture. The rate of proliferation in the $0 \mathrm{nmol} / \mathrm{l}$ group began to reduce at day 13 where it entered the platform stage; however, marked levels of proliferation were maintained in the $10 \mathrm{nmol} / \mathrm{l}$ group.

Effect of VEGF on EPC migration. Migration of EPCs was analyzed under various concentrations of $17 \beta$-estradiol. Migration was enhanced with increases in $17 \beta$-estradiol concentration. The number of cells migrating through the pores in the $10(18.7 \pm 4.5)$ and $100 \mathrm{nmol} / \mathrm{l}(37.4 \pm 9.4)$ groups was significantly higher than that of the $0 \mathrm{nmol} / \mathrm{l}$ group $(5.8 \pm 1.2)$ and migration in the $100 \mathrm{nmol} / \mathrm{l}$ group was found to be significantly higher than that of the $10 \mathrm{nmol} / 1$ group (Fig. 3; $\mathrm{P}<0.05$ ).

Effect of VEGF on in vitro EPC angiogenesis. EPCs revealed various angiogenic abilities in the fibrin gel following treatment with different concentrations of $17 \beta$-estradiol. In the $0 \mathrm{nmol} / \mathrm{l}$ group, a large number of isolated cells were observed in a scattered distribution and few connections between cells 

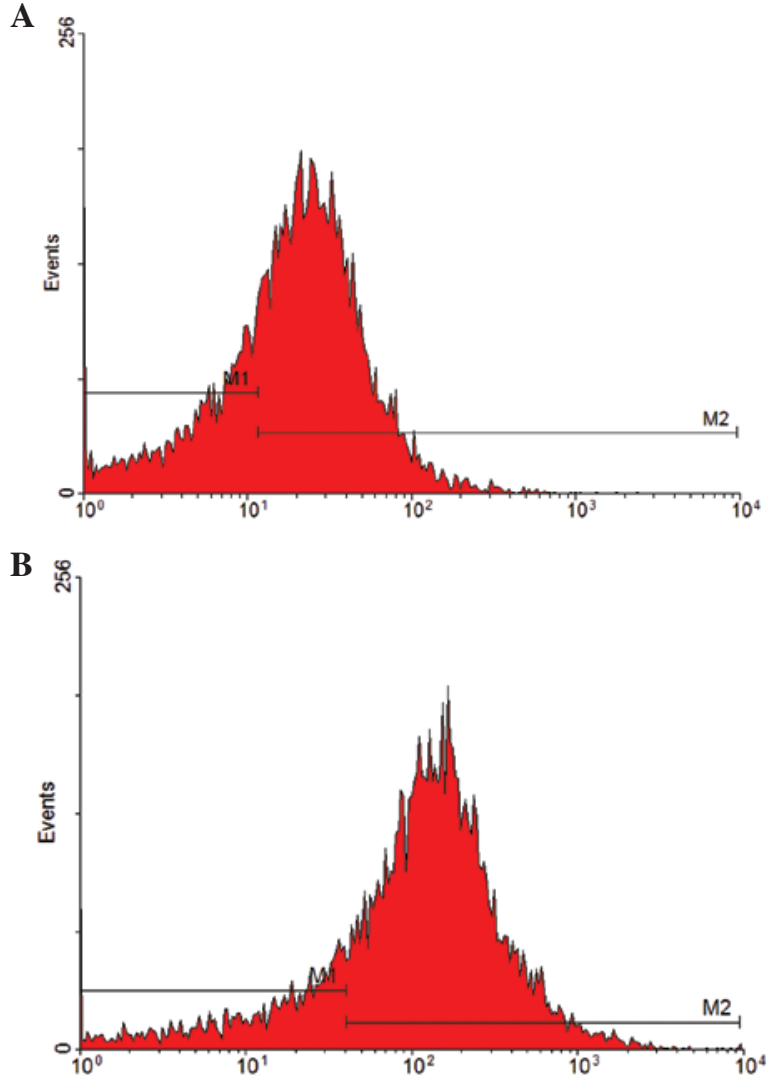

Figure 1. Flow cytometry analysis of (A) CD133 and (B) CD34 in endothelial progenitor cells.

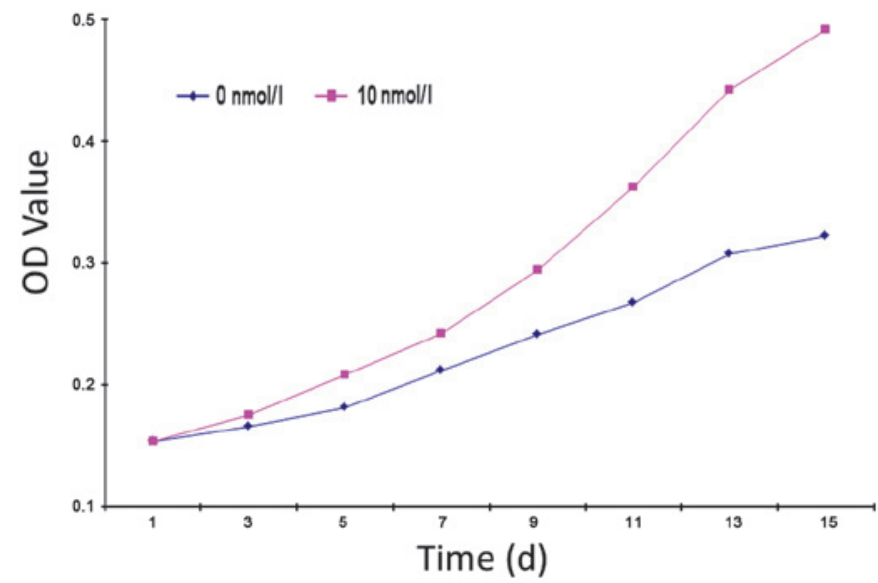

Figure 2. Growth curve of endothelial progenitor cells following treatment with 0 and $10 \mathrm{nmol} / 1$ 17ß-estradiol. OD, optical density.

were noted. In the $10 \mathrm{nmol} / 1$ group, vascular lumen formation was not found; however, the number of cells was higher than that in the $0 \mathrm{nmol} / \mathrm{l}$ group and connections between cells were observed. In the $100 \mathrm{nmol} / \mathrm{l}$ group, several cells are arranged in a circle and cells exhibited ring connections, constituting a blood vessel lumen. In addition, the formed lumen was rounder than that of the $10 \mathrm{nmol} / \mathrm{l}$ group (Fig. 3D-F). The total number of blood vessels in three randomly selected fields was $4.7 \pm 1.1$, $16.6 \pm 2.3$ and $27.8 \pm 4.2$ in the 0,10 and $100 \mathrm{nmol} / 1$ groups, respectively. The number of blood vessels in the $100 \mathrm{nmol} / \mathrm{l}$ group was significantly higher than that of the other groups

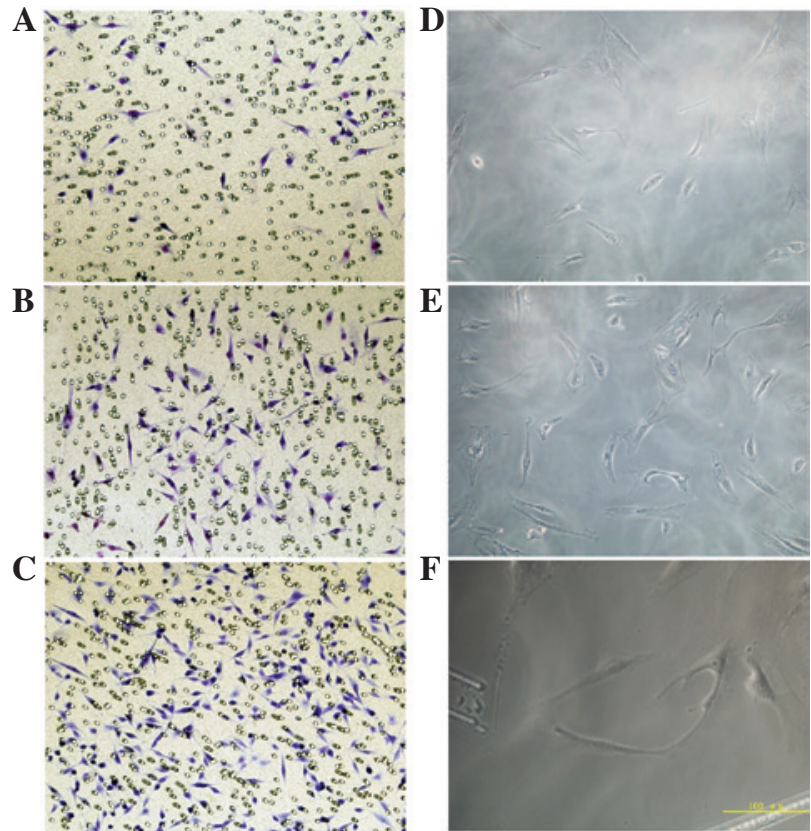

Figure 3. (A-C) Migration activity assay of EPCs. (D-F) In vitro vasculogenic activity assay of EPCs. Top to bottom: 0,10 and $100 \mathrm{nmol} / 1$ group. EPCs, endothelial progenitor cells.
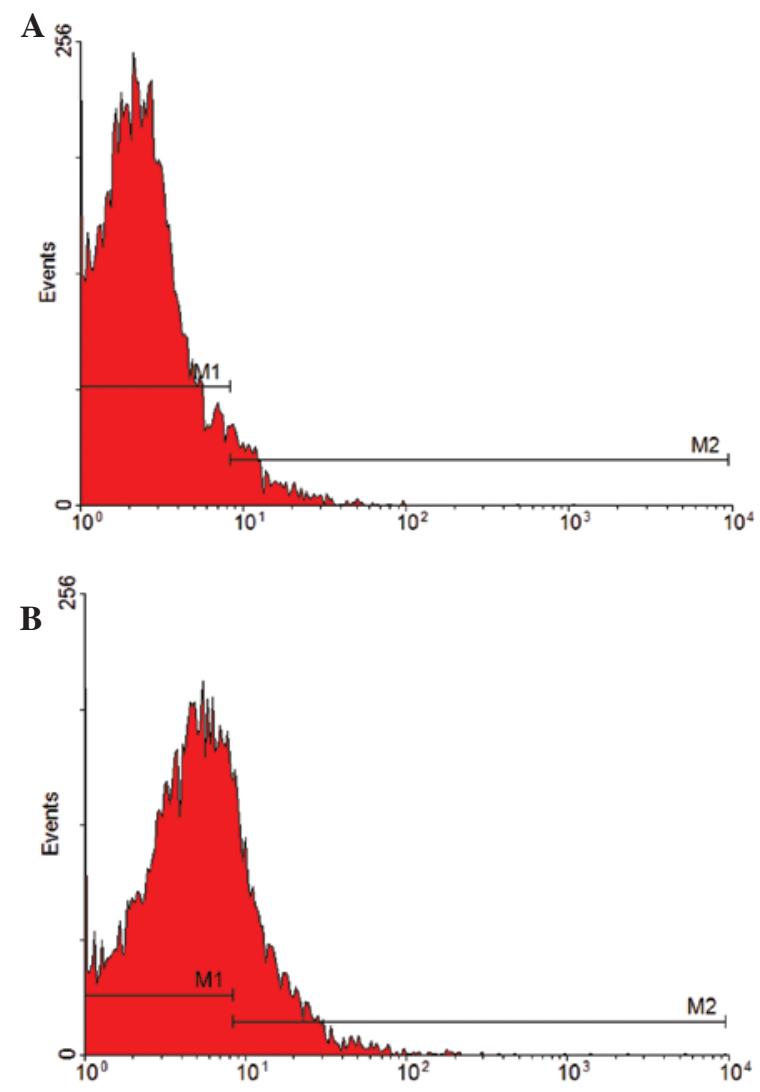

Figure 4. Flow cytometry analysis of endothelial progenitor cell differentiation.

$(\mathrm{P}<0.05)$, indicating that the $100 \mathrm{nmol} / \mathrm{l}$ group markedly promoted EPC vessel formation.

Effect of VEGF on EPC-induced differentiation. The specific surface marker of mature vascular endothelial cells, CD31, 
was analyzed to determine EPC differentiation. EPCs were cultured with various concentrations of $17 \beta$-estradiol (10 and $100 \mathrm{nmol} / \mathrm{l}$ ) and $0 \mathrm{nmol} / \mathrm{l}$ was used as a blank control to test the CD31-positive rate by flow cytometry. The CD31-positive rate was 6.65 and $23.30 \%$ in the 10 and $100 \mathrm{nmol} / 1$ groups, respectively (Fig. 4), indicating that $17 \beta$-estradiol induces EPC differentiation into mature endothelial cells. Compared with the $10 \mathrm{nmol} / 1$ group, the CD31-positive rate in $100 \mathrm{nmol} / \mathrm{l}$ was higher, indicating that EPC differentiation is accelerated by increasing $17 \beta$-estradiol concentrations.

\section{Discussion}

EPCs are the precursor cells of vascular endothelial cells and originate from the mesoderm, differentiating and developing from the angioblast. EPCs migrate to the peripheral circulation and differentiate into endothelial cells, repair damaged vascular endothelial cells and are important for maintaining the integrity of vascular endothelial cells (4). At present, there is no standard method to identify EPCs. One method involves the analysis of cell markers, including CD133, CD34 and other cell surface antigens. CD133 is expressed in the bone marrow, peripheral blood stem cells and early EPCs, but not in mature endothelial cells (5). Following differentiation of EPCs into mature endothelial cells, expression levels of CD133 decline. CD34 is a well-known marker of hematopoietic stem cells and is expressed in endothelial cells $(6,7)$. In the present study, CD133 and CD34 were used as specific markers for the identification of EPCs. Expression of the stem cell marker was found to gradually reduce as EPC culture progressed. However, the expression of CD31, a specific marker of endothelial cells was observed to increase (8), indicating that the cells had undergone differentiation into mature endothelial cells. As a result, CD31 was selected as a specific marker to determine the differentiation of EPCs towards a mature endothelial cell lineage.

Studies on the mechanisms by which estrogens mobilize endothelial cells have largely focused on the estrogen receptor (ER). However, to date, the number of ERs on endothelial progenitor cells has not been determined. As estrogen levels in normal tissues and vascular endothelia are low, the binding rate of estrogen and ERs is extremely low (9).

In the current study, EPCs were cultured in various concentrations of $17 \beta$-estradiol $(0,10$ and $100 \mathrm{nmol} / \mathrm{l})$ and $17 \beta$-estradiol was found to enhance EPC migration, improve in vitro angiogenesis and promote EPC differentiation towards mature vascular endothelial cells. With increases in the concentration of $17 \beta$-estradiol, this effect increased, revealing a dose-dependent correlation. When the concentration of $17 \beta$-estradiol was low (10 nmol/l), the number of EPCs increased and proliferation was enhanced. However, increased $17 \beta$-estradiol (100 nmol/l) concentration did not result in further increases in EPC proliferation. By contrast, proliferation was highest in the low concentration group and high concentrations of $17 \beta$-estradiol were revealed to have an inhibitory effect on EPC proliferation. It is possible that other signaling pathways are recruited at high estrogen concentrations (10).

In addition to regulating gene expression at the genomic level via nuclear receptors, $\alpha$ and $\beta$, estrogens also activate extracellular signals via non-genomic effects. Previous studies have reported that the association of estrogens with ER $\beta$ leads to the activation of the extracellular signal-regulated kinase/mitogen activated protein kinase (ERK/MAPK) (11). As a key signaling axis in signal transduction pathways involved in the growth, differentiation and apoptosis of cells, the MAPK family is activated by a number of mechanisms. Activated ERK improves the activity of the cytosolic target protein phosphorus to acidize or regulate other protein kinases, including activating the phospholipase A2 and regulating kinase translation, for example (12). In addition, activated ERK enters the cell nucleus to promote the phosphorylation of various transcription factors. For example, ERK promotes phosphorylation of serum response factor (SRF), enabling it to bind serum response elements in target gene promoters, enhancing transcriptional activity as well as accelerating cell proliferation. SRF not only regulates the transcription of a number of cell proliferation factors, but also exclusively controls the transcription of actin (13). Previous studies have found that RhoA is important for the reconstruction of actin in fibroblasts (14). Rho GTPases are involved in the dynamic regulation of the cytoskeleton in smooth muscle cells by activation of SRF (15), regulating the migration and angiogenesis of endothelial progenitor cells.

Estrogen promotes the proliferation, migration, angiogenesis and differentiation of EPCs, and complications, including thromboembolism, sodium and water retention and cancer, which may appear following the systemic application of estrogen. In the present study, in vitro administration of an appropriate concentration of $17 \beta$-estradiol to EPCs was found to maximize biological activity. The development of cell therapy combined with genetic tools has made it possible to use EPCs as the carriers for $17 \beta$-estradiol based gene therapy. This will allow for improved treatments to vascular system diseases, ischemia and would healing.

\section{References}

1. Callaghan MJ, Ceradini DJ and Gurtner GC: Hyperglycemiainduced reactive oxygen species and impaired endothelial progenitor cell function. Antioxid Redox Signal 7: 1476-1482, 2005.

2. Li HQ, Zhao Q and Sun XN: 17ß-Estradiol enhances migratory capacity of bone marrow-derived endothelial progenitor cells by up-regulating CXCR4 expression via estrogen receptors pathway. Zhong Hua Shi Yan Wai Ke Za Zhi She 26: 1407-1409, 2009.

3. Iwakura A,Shastry S,Luedemann C, et al: Estrogen enhances recovery after myocardial infarction by augmenting incorporation of bone marrow-derived endothelial progenitor cells into sites of ischemic-inducible neovascularization via endothelial nitric oxide synthase-mediated activation of matrix metalloproteinase-9. Circulation 113: 1605-1614, 2006.

4. Krenning G, van Luyn MJ and Harmsen MC: Endothelial progenitor cell-based neovascularization: implications for therapy. Trends Mol Med 15: 180-189, 2009.

5. Friedrich EB, Walenta K, Scharlau J, Nickenig G and Werner N: CD $34 / \mathrm{CD} 33^{+} / \mathrm{VEGFR}-2^{+}$endothelial progenitor cell subpopulation with potent vasoregenerative capacities. Circ Res 98: e20-e25, 2006.

6. Kwon SM, Eguchi M, Wada M, et al: Specific Jagged-1 signal from bone marrow microenvironment is required for endothelial progenitor cell development for neovascularization. Circulation 118: 157-165, 2008.

7. Nevskaya T, Bykovskaia S, Lyssuk E, et al: Circulating endothelial progenitor cells in systemic sclerosis: relation to impaired angiogenesis and cardiovascular manifestations. Clin Exp Rheumatol 26: 421-429, 2008.

8. Whittaker A, Moore JS, Vasa-Nicotera M, Stevens S and Samani NJ: Evidence for genetic regulation of endothelial progenitor cells and their role as biological markers of atherosclerotic susceptibility. Eur Heart J 29: 332-338, 2008 
9. Li HQ, Zhao Q, Sun X-N, et al: Effect of physiological estrogen on the migratory capacity of bone marrow-derived endothelial progenitor cells. Mol Cardiol Chin 45: 79-83, 2009.

10. Sims NA, Dupont S, Krust A, et al: Deletion of estrogen receptors reveals a regulatory role for estrogen receptors-beta in bone remodeling in females but not in males. Bone 30: 18-25, 2002.

11. Schwartz B, Smirnoff P, Shany S, et al: Estrogen controls expression and bioresponse of 1,25-dihydroxyvitamin D receptors in the rat colon. J Mol Cell Biochem 203: 87-93, 2000.

12. Walter DH, Haendeler J, Reinhold J, et al: Impaired CXCR4 signaling contributes to the reduced neovascularization capacity of endothelial progenitor cells from patients with coronary artery disease. Cirs Res 97: 1142-1151, 2005.
13. Posern G, Sotiropoulos A and Treisman R: Mutant actins demonstrate a role for unpolymerized actin in control of transcription by serum response factor. Mol Biol Cell 13: 4167-4178, 2002.

14. Amano M, Chihara K, Kimura K, et al: Formation of actin stress fibers and focal adhesions enhanced by Rho-kinase. Science 275 : 1308-1311, 1997.

15. Liu HW, Halayko AJ, Fernandes DJ, et al: The RhoA/Rho kinase pathway regulates nuclear localization of serum response factor. Am J Respir Cell Mol Biol 29: 39-47, 2003. 